\title{
Gemcitabine-oxaliplatin plus prednisolone is active in patients with castration-resistant prostate cancer for whom docetaxel-based chemotherapy failed
}

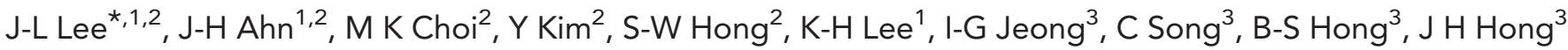
and $\mathrm{HAhn}{ }^{3}$

${ }^{1}$ Department of Medicine, Asan Medical Center, University of Ulsan College of Medicine, 88 Olympic-ro 43-gil, Songpa-gu, Seoul, Korea; ${ }^{2}$ Department of Oncology, Asan Medical Center, University of Ulsan College of Medicine, 88 Olympic-ro 43-gil, Songpa-gu, Seoul, Korea and ${ }^{3}$ Department of Urology, Asan Medical Center, University of Ulsan College of Medicine, 88 Olympic-ro 43-gil, Songpa-gu, Seoul, Korea
\end{abstract}

Background: There has been no previous study on the activity of gemcitabine in combination with oxaliplatin (GemOx) for castration-resistant prostate cancer (CRPC).

Methods: The GemOx was preclinically tested for cytotoxic activity in human prostate cancer cell lines. Clinically, patients with CRPC who failed prior docetaxel were treated with gemcitabine $1000 \mathrm{mg} \mathrm{m}^{-2}$ and oxaliplatin $100 \mathrm{mg} \mathrm{m}^{-2}$ intravenously every 2 weeks and prednisolone $5 \mathrm{mg}$ orally twice daily. The primary end point was the prostate-specific antigen (PSA) response rate.

Results: The GemOx displayed synergistic effects based on Chou and Talalay analysis. In the phase II study, 33 patients were accrued. The median dose of docetaxel exposure was $518 \mathrm{mg} \mathrm{m}^{-2}$. A total of 270 cycles were administered with a median of eight cycles per patient. A PSA response rate was $55 \%(95 \% \mathrm{Cl}, 38-72)$ and radiologic response rate was $82 \%$ (9 out of 11). With a median follow-up duration of 20.5 months, the median time to PSA progression was 5.8 months $(95 \% \mathrm{Cl}, 4.4-7.2)$ and the median overall survival was 17.6 months $(95 \% \mathrm{Cl}, 12.6-22.6)$. The most frequently observed grade 3 or 4 toxicities were neutropenia (13\%) and thrombocytopenia (13\%).

Conclusions: The GemOx is active and tolerable in patients with metastatic CRPC after docetaxel failure (NCT 01487720).

Standard of care in first-line symptomatic metastatic castrationresistant prostate cancer (mCRPC) is docetaxel-based chemotherapy. The SWOG 9916 and TAX327 studies revealed docetaxel with estramustine or prednisone could not only improve the quality of life and prostate-specific antigen (PSA) response, but also prolong the survival compared with mitoxantrone plus prednisone in mCRPC (Petrylak et al, 2004; Tannock et al, 2004). However, the efficacy of the drug has not been long-lasting and nearly all patients have disease progression in a median of 6-8 months (Lee et al, 2010). When progression develops on or after docetaxel, standard of care includes cabazitaxel, abiraterone, enzalutamide, or Radium-223 (de Bono et al, 2010, 2011; Scher et al, 2012; Parker et al, 2013). However, when this trial was designed, few treatment regimens could be applied to these patients that gave

\footnotetext{
*Correspondence: Dr J-L Lee; E-mail: jaelyun@amc.seoul.kr

Presented in part at the Genitourinary Cancer Symposium, 14-16 February 2013, Orlando, FL, USA and at the 5th European Multidisciplinary Meeting on Urological Cancer, 15-17 November, Marseille, France.
} 
a reasonable response and benefits after failure on a docetaxelbased regimen.

Gemcitabine is a nucleoside analogue with activity against a broad spectrum of solid tumours, such as pancreatic cancer, nonsmall cell lung cancer, bladder cancer, and ovary cancer (Hertel et al, 1990). In an in vitro model, gemcitabine exhibited a strong anti-proliferative and colony formation-inhibitory effect in prostate cancer cell lines (Cronauer et al, 1996). When gemcitabine alone was tried as first-line therapy for mCRPC, the PSA response rate was only $9 \%$, but the disease control rate (DCR) was $32 \%$ with a median duration of 7.1 months (Morant et al, 2000). When gemcitabine was combined with prednisone and zoledronic acid in pretreated patients with $\mathrm{mCRPC}$, the PSA response rate was $23 \%$ with a DCR of 57\% (Di Lorenzo et al, 2007).

Oxaliplatin causes DNA damage at the same sites of adduct formation as cisplatin does but overcomes cisplatin resistance in a wide range of solid tumours in vitro and in vivo (Mathe et al, 1989; Tashiro et al, 1989). Droz et al (2003) performed a phase II study in 54 patients with $\mathrm{mCRPC}$ who were randomised to receive oxaliplatin either alone or in combination with 5-fluorouracil. More than $50 \%$ of the patients had received prior chemotherapy, including cisplatin. Despite heavy pretreatment, PSA declines were noted in $11 \%$ and $19 \%$ of patients in each arm. During the conduction of the current study, a pilot trial of oxaliplatin and capecitabine including 14 patients with MCRPC after progression to docetaxel was reported. The results were promising: the PSA response rate was $57 \%$, with a median time to progression of 14.5 weeks with no unexpected toxicities (Gasent Blesa et al, 2011).

Gemcitabine plus oxaliplatin combination (GemOx) has been widely studied in pancreatic cancer and has been reported to be safe and effective in germ cell tumours even after intense prior treatments (Kollmannsberger et al, 2004; Louvet et al, 2005). Given the activity of single agents on mCRPC and the safety of the combination regimen in other solid cancers, further research on this combination is needed for patients with mCRPC (Santisteban et al, 2008). Therefore, we conducted a study to assess preclinical activity and synergism in a prostate cell line and to evaluate the clinical activity of GemOx in patients with MCRPC after failure of docetaxel-based regimens.

\section{MATERIALS AND METHODS}

Cell culture and cell viability assays. The human prostate cancer cell lines LNCaP, PC3, and DU145 were obtained from American Type Culture Collection (Manassas, VA, USA). All lines were maintained in RPMI-1640 medium supplemented with $10 \%$ fetal bovine serum and $1 \%$ penicillin/streptomycin. CellTiter 96 AQueous One Solution Cell Proliferation Assay (Promega, Madison, WI, USA) was used to determine cytotoxic effects after treatment with drugs. Cells were seeded at $2-3 \times 10^{3}$ cells per well in 96-well plates and then treated with various concentrations of gemcitabine (Sigma-Aldrich, St. Louis, MO, USA) or oxaliplatin (Sanofi-Aventis Korea, Seoul, Korea) or with a combination of gemcitabine and oxaliplatin (fixed concentration ratio of $5: 1$ ) for $72 \mathrm{~h}$. At the end of the treatment period, $20 \mu \mathrm{l}$ of $3-(4,5-$ dimethylthiazol-2-yl)-5-(3-carboxymethoxyphenyl)-2-(4-sulfophenyl)$2 \mathrm{H}$-tetrazolium(MTS) reagent was added to each well, and then incubated for $2 \mathrm{~h}$ at $37^{\circ} \mathrm{C}$. Cell viability was measured via the absorbance at $490 \mathrm{~nm}$ on a spectrophotometer (VICTOR X3; Perkin Elmer, Seoul, Korea) with a PerkinElmer 2030 Workstation software. Each experimental condition was performed in triplicate and repeated at least twice. All values were normalised with respect to the viability of untreated cells.

Evaluation of synergy. The combined drug effects were evaluated via Chou and Talalay analysis (Chou, 2010). This method involves the plotting of dose-effect curves for each drug and for multiply diluted, fixed-ratio combinations with the median-effect equation: $\left(\frac{\mathrm{fa}}{\mathrm{fu}}\right)=\left(\frac{D}{\mathrm{Dm}}\right)^{m}$, where $D$ is the dose of drug, fa is the fraction of cells affected by dose $(D)$, and fu is the fraction of unaffected cells (i.e., $\mathrm{fu}=1-\mathrm{fa}$ ). Dm is the median-effect dose (i.e., the dose at which $50 \%$ of cells are affected) and $m$ is a coefficient signifying the shape of the dose-effect relationship, where $m=1,>1$, and $<1$ indicate hyperbolic, sigmoidal, and flat sigmoidal dose-effect curves, respectively. In this equation, if the values for Dm and $m$ are known, then the dose $(D)$ for any given degree of effect (fa) can be determined. Based on this model, a combination index (CI) was calculated as: $\mathrm{CI}=\left[\frac{(D) \text { drug1 }}{(\mathrm{Da}) \operatorname{drug} 1}\right]+\left[\frac{(D) \text { drug2 }}{(\mathrm{Da}) \operatorname{drug} 2}\right]$, where the denominator $(\mathrm{Da})_{\text {drug } 1}$ is the dose of drug 1 that affects a fraction (fa) of cells when used alone and $(\mathrm{Da})_{\operatorname{drug} 2}$ is the dose of drug 2 that affects the same fraction ( $\mathrm{fa})$ of cells when used alone. The numerators, $(D)_{\mathrm{drug} 1}$ and $(D)_{\mathrm{drug} 2}$, are the doses of drugs 1 and 2 that when used in combination also affect the same fraction (fa) of the cells. If the sum of these two fractional terms is equal to 1 , then additivity is indicated. If the CI value is $<1$, then synergy is indicated, and if the CI value is $>1$, then antagonism is indicated. The experimental data were analysed with the CompuSyn software (Combosyn Inc., Paramus, NJ, USA).

Patients. Patients had pathologically proven prostate cancer and clinical or radiologic evidence of metastatic disease, with documented disease progression according to the Prostate Cancer Clinical Trials Working Group (PCWG) v2.0 criteria during or within 6 months of completion of docetaxel treatment (Scher et al, 2008). Eligible patients were at least 20 years of age, with an ECOG performance status of $0-2$ and a PSA level of $\geqslant 2.0 \mathrm{ng} \mathrm{ml}^{-1}$. Patients who had previous cytotoxic chemotherapy other than docetaxel, such as estramustine, mitoxantrone, etoposide, cyclophosphamide, or cabazitaxel, were also allowed to enter the study. Other inclusion criteria included previous and ongoing castration; antiandrogen withdrawal followed by progression that had to have taken place at least 6 weeks before enrollment, and adequate haematological, hepatic, renal, and cardiac function. Exclusion criteria included active grade 2 or worse peripheral neuropathy, prior $\beta$-particle-emitting radioisotope therapy, other tumour type other than adenocarcinoma, central nervous system metastasis, and any other serious medical, psychological, or social condition that would preclude study treatment. All patients were informed of the investigational nature of this study and signed a written informed consent. The protocol was approved by institutional review board (2008-0603) and registered at ClinicalTrials.gov (NCT01487720).

Chemotherapy. The combination of gemcitabine and oxaliplatin (GemOx) regimen comprised a gemcitabine $1000 \mathrm{mg} \mathrm{m}^{-2}$ intravenous infusion at a fixed dose rate $\left(10 \mathrm{mg} \mathrm{m}^{-2}\right.$ per minute) and a 2 -h intravenous infusion of oxaliplatin at a dose of $100 \mathrm{mg} \mathrm{m}^{-2}$ on day 1 . Treatment was repeated every 2 weeks. A maximum of 12 cycles of therapy were permitted unless patient refusal, unacceptable toxicity, or disease progression occurred.

Pretreatment and on-treatment evaluation. Pretreatment evaluations included a medical history, ECOG performance status, physical examination, laboratory screening, serum PSA concentration, CT, bone scan, and EKG. Pain and analgesic consumption were assessed at baseline. Pain was assessed with the McGillMelzack Present Pain Intensity (PPI) scale (Melzack, 1975) and analgesic score was derived from consumption normalised to morphine equivalents (Tannock et al, 1996). Physical examinations and blood tests were repeated before each treatment cycle and at the end of treatment. Prostate-specific antigen, PPI and analgesic score were checked every cycle, and bone scan and CT results were 
checked every 4 cycles ( 8 weeks). All adverse events were graded according to NCI CTCAE v 3.0 criteria.

Statistical consideration. This was an open label, single-centre, and phase II study. The primary end point was the frequency of PSA response defined by PCWG v.1.0 criteria (Bubley et al, 1999): PSA decline $\geqslant 50 \%$ confirmed with two consecutive measurements. In contrast to PCWG v.1.0, patients with a PSA level of 2-5 $\mathrm{ng} \mathrm{ml}{ }^{-1}$ were considered as evaluable for PSA response. Accrual of 33 patients was needed to detect a $30 \%$ PSA response rate compared with a null hypothesis of $\leqslant 10 \%$. A statistical level of significance of 0.05 , a power of $80 \%$, and a drop-out rate of $10 \%$ were assumed to test this hypothesis. Secondary end points included RECIST response, pain response (Melzack, 1975; Tannock et al, 1996), maximal and 12-week PSA decline, time to PSA progression, composite progression-free survival (PFS), and overall survival (OS). Composite progression was defined according to the PCWG v. 2.0 criteria as the occurrence of one or more of the following: PSA progression, progression of soft tissue disease per RECIST, bone scan progression (defined as the appearance of two or more lesions attributable to prostate cancer), skeletal event (defined as fracture or bone pain resulting in the need for radiotherapy or surgery), or symptomatic progression (defined as worsening of ECOG performance status and/or increased pain). Increase in pain was defined as the appearance of new pain or an increase in PPI score $\geqslant 2$ on two consecutive assessments at least 2 weeks apart.

\section{RESULTS}

Synergism in human prostate cancer cell lines. The 50\% inhibitory concentrations ( $\left.\mathrm{IC}_{50}\right)$ in single-drug experiments with $72 \mathrm{~h}$ exposure to gemcitabine and oxaliplatin were, respectively, 1.23 and $1.06 \mu \mathrm{M}$ for LNCaP cells, $2.06 \times 10^{6}$ and $5.66 \mu \mathrm{M}$ for PC3 cells, and 9.92 and $9.06 \mu \mathrm{M}$ for DU145 cells (Table 1). The sensitivity to gemcitabine and oxaliplatin was higher in LNCaP cells than in DU145 cells. PC3 cells were relatively refractory to gemcitabine but sensitive to oxaliplatin. The $\mathrm{CI}$ values at concentrations corresponding to fraction affected ( $\mathrm{fa}$ ) of 0.5 , $0.75,0.9$, and 0.95 are summarised in Table 2. Gemcitabineoxaliplatin combinations displayed synergistic effects in three cell lines, with the synergism most pronounced in LNCaP cell lines. However, in the PC3 cells, the gemcitabine-oxaliplatin combination suggested partial antagonism for concentrations corresponding to an fa of 0.9 .

Patient demographics. Between 23 December 2009 and 27 November 2012, 33 patients were enrolled in this study. The patient and disease characteristics are summarised in Table 3. Of the 33 patients, $33 \%$ had measurable disease and $42 \%$ had visceral metastases. The median dose of docetaxel received before the study was $518 \mathrm{mg} \mathrm{m}^{-2}$ (interquartile range, 316-870), and only one patient $(3 \%)$ received a cumulative dose of docetaxel $<225 \mathrm{mg} \mathrm{m}^{-2}$. About $77 \%$ of patients had progressive disease during docetaxel treatment.

Efficacy. Post-chemotherapy 12-week and maximal PSA decline following treatment is shown in Figure 1. A PSA response was seen in 18 of 32 evaluable patients (55\%; 95\% confidence interval (CI), $38-72 \%)$. The PSA response was not available in one patient who had died of viral pneumonia after first cycle. Among 11 patients with measurable disease, 9 achieved partial response and 2 had stable disease with a response rate of $82 \%$. Pain response was observed in 13 of 24 patients (54\%) with baseline PPI $\geqslant 2$. With a median follow-up duration of 20.5 months with reverse Kaplan-Meier methods (Shuster, 1991) (95\% CI, 14.5-26.7), the median time to PSA progression was 5.8 months (95\% CI, 4.4-7.2;
Table 1. Effects of gemcitabine and oxaliplatin alone or in combination on prostate cancer cell lines

\begin{tabular}{|c|c|c|c|}
\hline & \multicolumn{3}{|c|}{$I C_{50}{ }^{a}$} \\
\hline $\begin{array}{l}\text { Cell } \\
\text { lines }\end{array}$ & $\begin{array}{c}\text { Gemcitabine } \\
(\mu \mathrm{M})\end{array}$ & $\begin{array}{l}\text { Oxaliplatin } \\
\qquad(\mu \mathrm{M})\end{array}$ & $\begin{array}{c}\text { GemOx }(5: 1) \\
(\mu \mathrm{M})\end{array}$ \\
\hline LNCaP & 1.23 & 1.06 & 0.53 \\
\hline DU145 & 9.92 & 9.06 & 3.73 \\
\hline PC3 & $2.06 \times 10^{5}$ & 5.66 & 7.22 \\
\hline \multicolumn{4}{|c|}{ 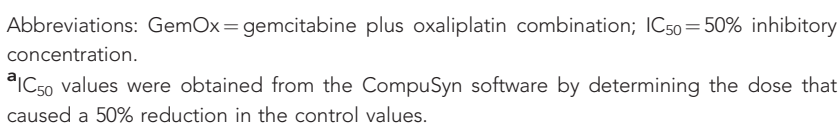 } \\
\hline
\end{tabular}

Table 2. Combination index $(\mathrm{Cl})$ values of gemcitabine plus oxaliplatin $(5: 1)$ at concentrations corresponding to a fraction affected ( $\mathrm{fa}$ ) of 0.5 and above in prostate cancer cell lines

\begin{tabular}{|l|c|c|c|c|}
\hline \multicolumn{4}{|c|}{ Cl } \\
\hline Cell lines & fa 0.5 & fa 0.75 & fa 0.9 & fa 0.95 \\
\hline LNCaP & 0.44 & 0.12 & 0.12 & 0.14 \\
\hline DU145 & 0.38 & 0.21 & 0.18 & 0.20 \\
\hline PC3 & 0.21 & 0.57 & 1.52 & 2.97 \\
\hline
\end{tabular}

Figure 2) and median composite PFS was 5.4 months (95\% CI, 3.5-7.3). At the time of this analysis (30 July 2013), 17 patients had died and the median OS was 17.6 months (95\% CI, 12.6-22.6; Figure 2) with a 1-year survival rate of $65 \%$.

Treatment exposure. A total of 270 cycles were administered with a median number of cycles of 8 (range, 1-12). The median total cumulative doses of oxaliplatin and gemcitabine were $825 \mathrm{mg} \mathrm{m}^{-2}$ (range, 100-1200) and $8250 \mathrm{mg} \mathrm{m}^{-2}$, respectively. The relative dose intensity of GemOx was 77.8\% (range, 54.4-99.4). Dose reductions were reported for 6 patients (18\%) and treatment delays occurred in 25 patients $(76 \%)$. The primary reason for treatment discontinuation was disease progression $(n=13,49 \%)$, followed by toxicity $(n=8,24 \%)$. Other reasons included concomitant infection ( $n=2$, pulmonary mycobacterial infection), aggravation of chronic obstructive pulmonary disease $(n=1)$, and refusal $(n=2)$. Seven patients $(21 \%)$ completed the planned twelve cycles of chemotherapy.

Adverse events. The frequencies of haematological and nonhaematological adverse events are shown in Table 4. Events of haematologic grade 3-4 toxicity included neutropenia (13\%), thrombocytopenia (13\%), leukopenia (10\%), febrile neutropenia (urinary tract infection associated with neutropenia, 3\%), and anaemia $(3 \%)$. The majority of non-haematologic toxicities were grade 2 or less and peripheral sensory neuropathy was the most common (39\%) non-haematologic grade 2 toxicity, followed by asthenia (23\%) and stomatitis (23\%). Three patients died within 30 days of the last protocol treatment. After the seventh cycle of GemOx therapy, grade 5 upper gastrointestinal bleeding occurred in a 67-year-old patient who had disseminated lung and liver metastases that were markedly improved with protocol therapy. This event was managed at the local hospital and the exact cause of bleeding was not reported. Grade 5 viral (parainfluenza virus and rhinovirus) pneumonia occurred 4 weeks after completion of the 


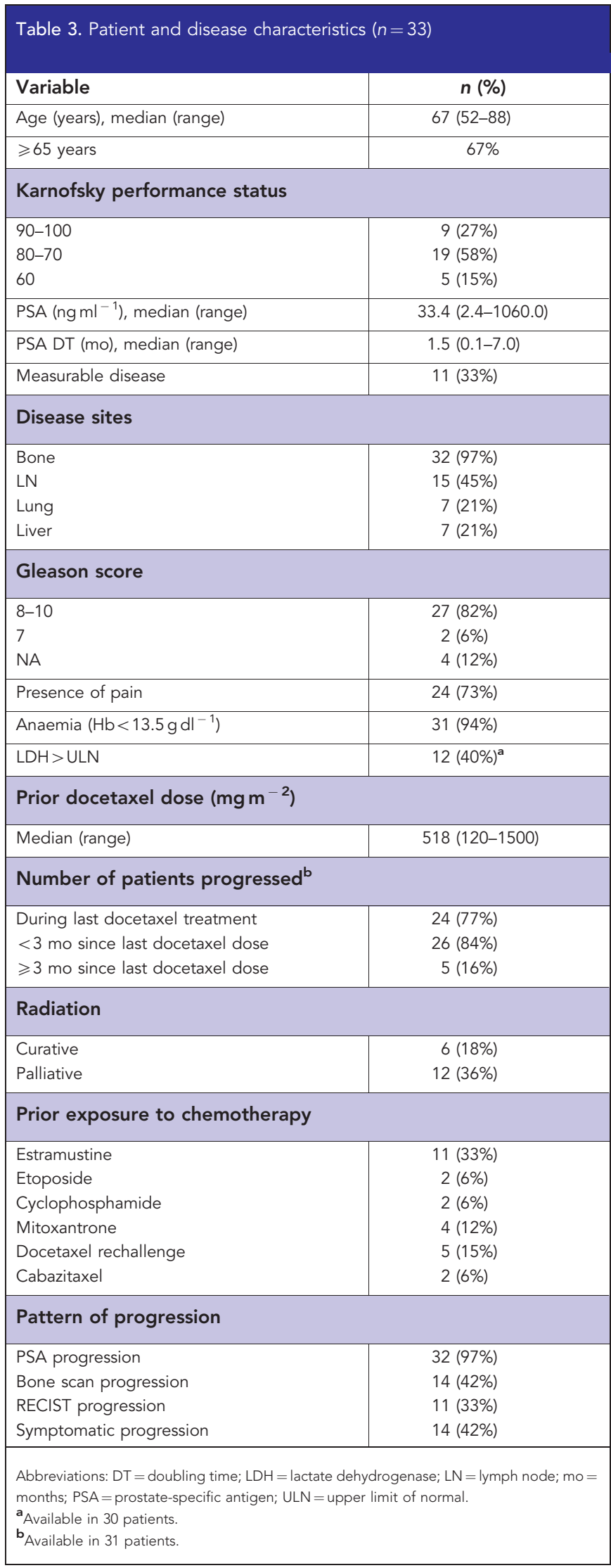

last cycle of protocol therapy in a 62-year-old patient. The third and final patient to die also suffered from grade 5 viral pneumonia with grade 4 neutropenia that occurred on day 7 after the first cycle of protocol therapy. In all cases, the direct causal relationship with the protocol therapy was difficult to determine.
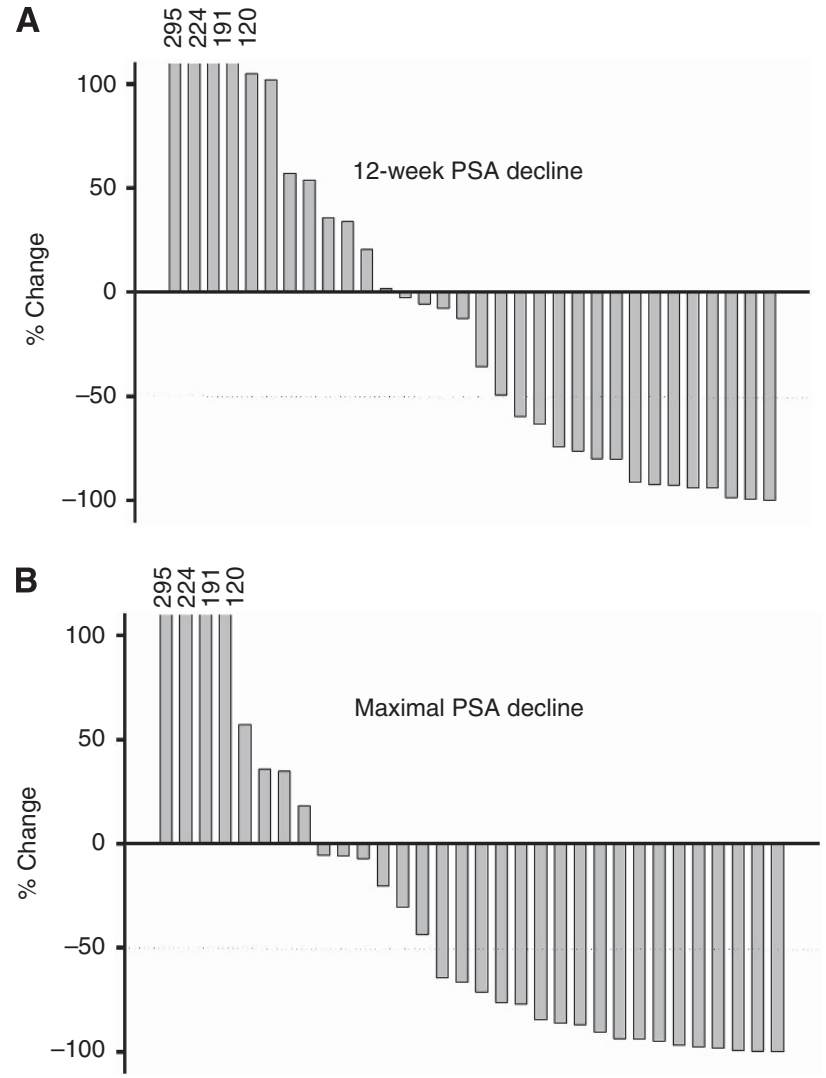

Figure 1. Post-chemotherapy 12-week (A) and maximal PSA decline (B) following gemcitabine plus oxaliplatin combination chemotherapy.

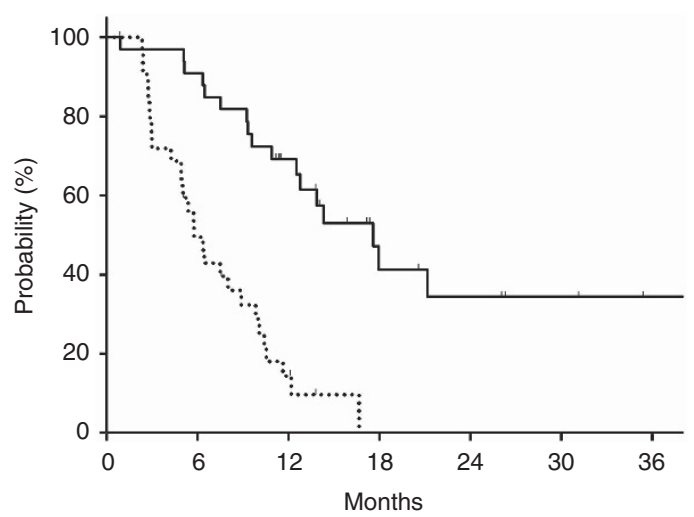

Figure 2. Time to PSA progression (dotted line) and overall survival (solid line) in patients with $\mathrm{mCRPC}$ treated with GemOx combination chemotherapy after failure of docetaxel.

Salvage therapy. After disease progression, 25 patients (76\%) received subsequent therapy: cabazitaxel was administered in 17 and abiraterone was administered in 8. Metronomic oral cyclophosphamide therapy was given in 8 patients. Other treatments included docetaxel retrial $(n=2)$, estramustine $(n=2)$, and enzalutamide $(n=2)$.

\section{DISCUSSION}

Our study showed synergistic activity between gemcitabine and oxaliplatin in a range of human prostate cancer cell lines. Based on encouraging preclinical results, a phase II study of a gemcitabine 
Table 4. Adverse events possibly related to treatment $(n=31)$ by grade

No. of patients (\%)

\begin{tabular}{|l|c|c|c|c|}
\hline Adverse events & Grade 1 & Grade 2 & Grade 3 & Grade 4 \\
\hline Anaemia & $13(42)$ & $8(26)$ & $1(3)$ & 0 \\
\hline Leukopenia & $2(6)$ & $5(16)$ & $2(6)$ & $1(3)$ \\
\hline Neutropenia & $7(23)$ & $2(6)$ & $3(10)$ & $1(3)$ \\
\hline Thrombocytopenia & $8(26)$ & $2(6)$ & $3(10)$ & $1(3)$ \\
\hline Neutropenic infection ${ }^{\text {a }}$ & 0 & 0 & $1(3)$ & 0 \\
\hline Non-neutropenic infection & 0 & $1(3)$, pneumonia & $1(3)$, colitis & 0 \\
\hline Transaminitis & $2(6)$ & $1(3)$ & 0 & 0 \\
\hline Asthenia & $10(32)$ & $7(23)$ & 0 & 0 \\
\hline Anorexia & $10(32)$ & $6(19)$ & 0 & 0 \\
\hline Nausea & $4(13)$ & $2(6)$ & 0 & 0 \\
\hline Vomiting & $2(6)$ & 0 & 0 & 0 \\
\hline Stomatitis & $4(13)$ & $7(23)$ & 0 & 0 \\
\hline Diarrhoea & $2(6)$ & $1(3)$ & $2(6)$ & 0 \\
\hline Sensory neuropathy & $15(48)$ & $12(39)$ & 0 & 0 \\
\hline Motor neuropathy & $5(16)$ & $5(16)$ & 0 & 0 \\
\hline Allergy & $1(3)$ & $1(3)$ & & \\
\hline Rash & $1(3)$ & $1(3)$ & & \\
\hline $\begin{array}{l}\text { a Neutropenic infection grade 5, viral pneumonia at first cycle day } 7 . \\
\text { b Non-neutropenic infection grade 5, viral pneumonia after seventh cycle of chemotherapy. }\end{array}$ \\
\hline
\end{tabular}

and oxaliplatin combination was conducted. This regimen showed promising efficacy, especially in terms of PSA response (55\%) and soft tissue response (82\%), which were accompanied by a pain response (54\%) with an acceptable toxicity profile in patients with mCRPC with prior docetaxel failure.

The PSA and soft tissue responses achieved with GemOx compare favourably with the results of newly approved agents, such as cabazitaxel (39\% and $14 \%$, respectively), abiraterone $(29 \%$ and $14 \%$, respectively), and enzalutamide (54\% and $29 \%$, respectively) and far better than those of mitoxantrone-prednisone (18\% and $4 \%$, respectively), which was the de facto standard worldwide when this trial was designed and the only agent reimbursed by public health insurance systems in Asian countries, including Korea, even after the approval of newer agents (de Bono et al, 2010, 2011; Scher et al, 2012). The composite PFS of 5.4 months of GemOx was better than the 2.8-month PFS of cabazitaxel, which had adopted the same definition of composite progression and comparable with the 5.6-month radiographic PFS of abiraterone (de Bono et al, 2010, 2011). Notably, the response rate was not inferior in patients with visceral metastases; in fact, the response rates seemed to be higher in patients with visceral metastases. As widely known, visceral metastases, such as liver or lung metastases, are, unlike bone or lymph-node metastases, not common and are regarded as late events in the course of disease progression and reported to be associated with anaplastic mCRPC with or without neuroendocrine differentiation (Aparicio et al, 2013). Platinum-based chemotherapy is the main therapeutic agent for neuroendocrine carcinoma, and this might be the reason why a higher response was achieved in patients with visceral metastases (Loriot et al, 2009; Aparicio et al, 2013).

The high rate of pain response (54\%) indicates the palliative role of this combination, which would be based on a favourable antitumour response and high tolerability. Although, comparison between trials is difficult and might be misleading, the pain response achieved with GemOx looked better than those observed for mitoxantrone-prednisone (8-29\%) or cabazitaxel (9\%), and comparable to those achieved with abiraterone (44\%) (Tannock et al, 1996; de Bono et al, 2010).

The safety of this regimen seems to be acceptable. The level of haematologic toxicities observed in the current study compares favourably with that observed in the mitoxantrone-prednisone study and seems to be better than that of cabazitaxel (Tannock et al, 1996; de Bono et al, 2010). Although survival benefits have been proven with cabazitaxel, the toxicity is not negligible in elderly and frail patients, and the majority of patients need granulocyte colony-stimulating factor, with or without antibiotic prophylaxis. Although older and frailer patients were included in the current study and GemOx was given as a second-line therapy after docetaxel failure, the incidence and severity of adverse events in this study was similar to those of the E6201 study, which used GemOx as the first-line therapy against advanced pancreatic cancer (Poplin et al, 2009). However, as expected the incidence of cumulative peripheral sensory neuropathy (grade 2 in 39\%), especially in patients who had already have docetaxel-associated or other neuropathy, was significant and $15 \%$ of patients refused further treatment due to neuropathy. In addition, there were three treatment-related mortality cases; one gastrointestinal bleeding and two viral pneumoniae, one of which was accompanied by grade IV neutropenia. Although their direct causal relationship with study medication was difficult to derive as viral pneumonia was prevalent at that time, it alarms us that cytotoxic agents that have favourable toxicity profile in general population could lead to life-threatening outcome in this kind of frail populations.

For about a half century, platinum drugs have formed a cornerstone of the chemotherapy regimen for various malignancies. Its role in patients with MCRPC has also been studied (Choy et al, 2008). Conventional cisplatin or carboplatin has shown only modest activity on mCRPC when used in monotherapy or in combination with taxanes (Oh et al, 2007; Nakabayashi et al, 2008; Ross et al, 2008; Buonerba et al, 2011). Next-generation platinum agents, such as oxaliplatin and satraplatin, have better activity because diaminocyclohexane or asymmetrical amine and cyclohexamine platinum adducts from oxaliplatin and satraplatin, respectively, are not recognised by the mismatch repair (MMR) complex that recognises and repairs DNA damage inflicted by conventional platinum (Fink et al, 1996). The MMR defects, which have been regarded as one mechanism of cisplatin or carboplatin resistance, are prevalent in prostate cancer (Chen et al, 2001). Although the results of the SPARC phase III study have not shown an increase in OS with the use of satraplatin in the second-line setting, they did show a clinically and statistically significant benefit in time to progression, PSA response, pain response, and quality of life (Sternberg et al, 2009). The current study also showed the significant activity of oxaliplatin when combined with gemcitabine in mCRPC after failure of docetaxel. Further exploration of the use of platinum in MCRPC is warranted and could provide interesting insights, and platinum might be a viable treatment option in the future.

In conclusion, the GemOx combination chemotherapy is very active in patients with $\mathrm{MCRPC}$ after docetaxel failure. The PSA, soft tissue, and pain responses observed with this combination are promising and this regimen deserves further investigation.

\section{ACKNOWLEDGEMENTS}

We thank the patients and their families who took part in this study, the coordinators and the investigators. We also thank Chong Kun Dang Pharmaceutical Co. and Boryung Co. for their kind donation of gemcitabine (Gemtan) and oxaliplatin (Oxalitin), respectively. This study was supported by a grant 
(HI12C17880300) from the Korean Health Technology R\&D Project, Ministry of Health and Welfare, and a grant (2011K00871) from Converging Research Center Program for the Ministry of Education, Science and Technology, Republic of Korea.

\section{CONFLICT OF INTEREST}

The authors declare no conflict of interest.

\section{REFERENCES}

Aparicio AM, Harzstark AL, Corn PG, Wen S, Araujo JC, Tu S-M, Pagliaro LC, Kim J, Millikan RE, Ryan C, Tannir NM, Zurita AJ, Mathew P, Arap W, Troncoso P, Thall PF, Logothetis CJ (2013) Platinum-based chemotherapy for variant castrate-resistant prostate cancer. Clin Cancer Res 19(13): 3621-3630.

Bubley GJ, Carducci M, Dahut W, Dawson N, Daliani D, Eisenberger M, Figg WD, Freidlin B, Halabi S, Hudes G, Hussain M, Kaplan R, Myers C, Oh W, Petrylak DP, Reed E, Roth B, Sartor O, Scher H, Simons J, Sinibaldi V, Small EJ, Smith MR, Trump DL, Vollmer R, Wilding G (1999) Eligibility and response guidelines for phase II clinical trials in androgenindependent prostate cancer: recommendations from the Prostate-Specific Antigen Working Group. J Clin Oncol 17(11): 3461-3467.

Buonerba C, Federico P, D'Aniello C, Rescigno P, Cavaliere C, Puglia L, Ferro M, Altieri V, Perdonà S, De Placido S, Lorenzo G (2011) Phase II trial of cisplatin plus prednisone in docetaxel-refractory castrationresistant prostate cancer patients. Cancer Chemother Pharmacol 67(6): 1455-1461.

Chen Y, Wang J, Fraig MM, Metcalf J, Turner WR, Bissada NK, Watson DK, Schweinfest CW (2001) Defects of DNA mismatch repair in human prostate cancer. Cancer Res 61(10): 4112-4121.

Chou TC (2010) Drug combination studies and their synergy quantification using the Chou-Talalay method. Cancer Res 70(2): 440-446.

Choy H, Park C, Yao M (2008) Current status and future prospects for satraplatin, an oral platinum analogue. Clin Cancer Res 14(6): 1633-1638.

Cronauer MV, Klocker H, Talasz H, Geisen FH, Hobisch A, Radmayr C, Böck G, Culig Z, Schirmer M, Reissigl A, Bartsch G, Konwalinka G (1996) Inhibitory effects of the nucleoside analogue gemcitabine on prostatic carcinoma cells. Prostate 28(3): 172-181.

de Bono JS, Logothetis CJ, Molina A, Fizazi K, North S, Chu L, Chi KN, Jones RJ, Goodman OB, Saad F, Staffurth JN, Mainwaring P, Harland S, Flaig TW, Hutson TE, Cheng T, Patterson H, Hainsworth JD, Ryan CJ, Sternberg CN, Ellard SL, Fléchon A, Saleh M, Scholz M, Efstathiou E, Zivi A, Bianchini D, Loriot Y, Chieffo N, Kheoh T, Haqq CM, Scher HI (2011) Abiraterone and increased survival in metastatic prostate cancer. N Engl J Med 364(21): 1995-2005.

de Bono JS, Oudard S, Ozguroglu M, Hansen S, Machiels J-P, Kocak I, Gravis G, Bodrogi I, Mackenzie MJ, Shen L, Roessner M, Gupta S, Sartor AO (2010) Prednisone plus cabazitaxel or mitoxantrone for metastatic castration-resistant prostate cancer progressing after docetaxel treatment: a randomised open-label trial. Lancet 376(9747): 1147-1154.

Di Lorenzo G, Autorino R, Giuliano M, Morelli E, Giordano A, Napodano G, Russo A, Benincasa G, D’Armiento M, Altieri V, De Placido S (2007) Phase II trial of gemcitabine, prednisone, and zoledronic acid in pretreated patients with hormone refractory prostate cancer. Urology 69(2): 347-351.

Droz JP, Muracciole X, Mottet N, Ould Kaci M, Vannetzel JM, Albin N, Culine S, Rodier JM, Misset JL, Mackenzie S, Cvitkovic E, Benoit G (2003) Phase II study of oxaliplatin versus oxaliplatin combined with infusional 5 -fluorouracil in hormone refractory metastatic prostate cancer patients. Ann Oncol 14(8): 1291-1298.

Fink D, Nebel S, Aebi S, Zheng H, Cenni B, Nehme A, Christen RD, Howell SB (1996) The role of DNA mismatch repair in platinum drug resistance. Cancer Res 56(21): 4881-4886.

Gasent Blesa JM, Giner Marco V, Giner-Bosch V, Cerezuela Fuentes P, Alberola Candel V (2011) Phase II trial of oxaliplatin and capecitabine after progression to first-line chemotherapy in androgen-independent prostate cancer patients. Am J Clin Oncol 34(2): 155-159.

Hertel LW, Boder GB, Kroin JS, Rinzel SM, Poore GA, Todd GC, Grindey GB (1990) Evaluation of the antitumor activity of gemcitabine $\left(2^{\prime}, 2^{\prime}\right.$-difluoro$2^{\prime}$-deoxycytidine). Cancer Res 50(14): 4417-4422.
Kollmannsberger C, Beyer J, Liersch R, Schoeffski P, Metzner B, Hartmann JT, Rick O, Stengele K, Hohloch K, Spott C, Kanz L, Bokemeyer C (2004) Combination chemotherapy with gemcitabine plus oxaliplatin in patients with intensively pretreated or refractory germ cell cancer: a study of the German Testicular Cancer Study Group. J Clin Oncol 22(1): 108-114.

Lee J-L, Kim JE, Ahn J-H, Lee D-H, Lee J, Kim C-S, Hong JH, Hong B, Song C, Ahn H (2010) Efficacy and safety of docetaxel plus prednisolone chemotherapy for metastatic hormone-refractory prostate adenocarcinoma: single institutional study in Korea. Cancer Res Treat 42(1): 12-17.

Loriot Y, Massard C, Gross-Goupil M, Di Palma M, Escudier B, Bossi A, Fizazi K (2009) Combining carboplatin and etoposide in docetaxelpretreated patients with castration-resistant prostate cancer: a prospective study evaluating also neuroendocrine features. Ann Oncol 20(4): 703-708.

Louvet C, Labianca R, Hammel P, Lledo G, Zampino MG, André T, Zaniboni A, Ducreux M, Aitini E, Taïeb J, Faroux R, Lepere C, de Gramont A (2005) Gemcitabine in combination with oxaliplatin compared with gemcitabine alone in locally advanced or metastatic pancreatic cancer: Results of a GERCOR and GISCAD phase III trial. J Clin Oncol 23(15): 3509-3516.

Mathe G, Kidani Y, Segiguchi M, Eriguchi M, Fredj G, Peytavin G, Misset JL, Brienza S, de Vassals F, Chenu E (1989) Oxalato-platinum or 1-OHP, a third-generation platinum complex: an experimental and clinical appraisal and preliminary comparison with cis-platinum and carboplatinum. Biomed Pharmacother 43(4): 237-250.

Melzack R (1975) The McGill Pain Questionnaire: major properties and scoring methods. Pain 1(3): 277-299.

Morant R, Bernhard J, Maibach R, Borner M, Fey MF, Thurlimann B, Jacky E, Trinkler F, Bauer J, Zulian G, Hanselmann S, Hurny C, Hering F. for the Swiss Group for Clinical Cancer R (2000) Response and palliation in a phase II trial of gemcitabine in hormone-refractory metastatic prostatic carcinoma. Ann Oncol 11(2): 183-188.

Nakabayashi M, Sartor O, Jacobus S, Regan MM, McKearn D, Ross RW, Kantoff PW, Taplin ME, Oh WK (2008) Response to docetaxel/ carboplatin-based chemotherapy as first- and second-line therapy in patients with metastatic hormone-refractory prostate cancer. BJU Int 101(3): 308-312.

Oh WK, Tay M-H, Huang J (2007) Is there a role for platinum chemotherapy in the treatment of patients with hormone-refractory prostate cancer? Cancer 109(3): 477-486.

Parker C, Nilsson S, Heinrich D, Helle SI, O'Sullivan JM, Fossa SD, Chodacki A, Wiechno P, Logue J, Seke M, Widmark A, Johannessen DC, Hoskin P, Bottomley D, James ND, Solberg A, Syndikus I, Kliment J, Wedel S, Boehmer S, Dall'Oglio M, Franzen L, Coleman R, Vogelzang NJ, O'Bryan-Tear CG, Staudacher K, Garcia-Vargas J, Shan M, Bruland OS, Sartor O (2013) Alpha emitter radium-223 and survival in metastatic prostate cancer. N Engl J Med 369(3): 213-223.

Petrylak DP, Tangen CM, Hussain MHA, Lara Jr PN, Jones JA, Taplin ME, Burch PA, Berry D, Moinpour C, Kohli M, Benson MC, Small EJ, Raghavan D, Crawford ED (2004) Docetaxel and estramustine compared with mitoxantrone and prednisone for advanced refractory prostate cancer. N Engl J Med 351(15): 1513-1520.

Poplin E, Feng Y, Berlin J, Rothenberg ML, Hochster H, Mitchell E, Alberts S, O’Dwyer P, Haller D, Catalano P, Cella D, Benson 3rd AB (2009) Phase III, randomized study of gemcitabine and oxaliplatin versus gemcitabine (fixed-dose rate infusion) compared with gemcitabine (30-minute infusion) in patients with pancreatic carcinoma E6201: a trial of the Eastern Cooperative Oncology Group. J Clin Oncol 27(23): 3778-3785.

Ross RW, Beer TM, Jacobus S, Bubley GJ, Taplin ME, Ryan CW, Huang J, Oh WK (2008) A phase 2 study of carboplatin plus docetaxel in men with metastatic hormone-refractory prostate cancer who are refractory to docetaxel. Cancer 112(3): 521-526.

Santisteban M, Perez-Gracia JL, Ceballos J, Vivas I, Garcia-Foncillas J (2008) Oxaliplatin plus gemcitabine as a salvage schedule for hormone-refractory prostate adenocarcinoma. Clin Transl Oncol 10(6): 372-374.

Scher HI, Fizazi K, Saad F, Taplin ME, Sternberg CN, Miller K, de Wit R, Mulders P, Chi KN, Shore ND, Armstrong AJ, Flaig TW, Flechon A, Mainwaring P, Fleming M, Hainsworth JD, Hirmand M, Selby B, Seely L, de Bono JS (2012) Increased survival with enzalutamide in prostate cancer after chemotherapy. N Engl J Med 367(13): 1187-1197.

Scher HI, Halabi S, Tannock I, Morris M, Sternberg CN, Carducci MA, Eisenberger MA, Higano C, Bubley GJ, Dreicer R, Petrylak D, Kantoff P, 
Basch E, Kelly WK, Figg WD, Small EJ, Beer TM, Wilding G, Martin A, Hussain M (2008) Design and end points of clinical trials for patients with progressive prostate cancer and castrate levels of testosterone: recommendations of the Prostate Cancer Clinical Trials Working Group. J Clin Oncol 26(7): 1148-1159.

Shuster JJ (1991) Median follow-up in clinical trials. J Clin Oncol 9(1): 191-192.

Sternberg CN, Petrylak DP, Sartor O, Witjes JA, Demkow T, Ferrero JM, Eymard JC, Falcon S, Calabro F, James N, Bodrogi I, Harper P, Wirth M, Berry W, Petrone ME, McKearn TJ, Noursalehi M, George M, Rozencweig M (2009) Multinational, double-blind, phase III study of prednisone and either satraplatin or placebo in patients with castraterefractory prostate cancer progressing after prior chemotherapy: the SPARC trial. J Clin Oncol 27(32): 5431-5438.

Tannock IF, de Wit R, Berry WR, Horti J, Pluzanska A, Chi KN, Oudard S, Theodore C, James ND, Turesson I, Rosenthal MA, Eisenberger MA. the TAXI (2004) Docetaxel plus prednisone or mitoxantrone plus prednisone for advanced prostate cancer. N Engl J Med 351(15): 1502-1512. Tannock IF, Osoba D, Stockler MR, Ernst DS, Neville AJ, Moore MJ, Armitage GR, Wilson JJ, Venner PM, Coppin CM, Murphy KC (1996) Chemotherapy with mitoxantrone plus prednisone or prednisone alone for symptomatic hormone-resistant prostate cancer: a Canadian randomized trial with palliative end points. J Clin Oncol 14(6): 1756-1764. Tashiro T, Kawada Y, Sakurai Y, Kidani Y (1989) Antitumor activity of a new platinum complex, oxalato (trans-1-1,2-diaminocyclohexane)platinum (II): new experimental data. Biomed Pharmacother 43(4): 251-260.

This work is published under the standard license to publish agreement. After 12 months the work will become freely available and the license terms will switch to a Creative Commons AttributionNonCommercial-Share Alike 3.0 Unported License. 